\title{
Reframing citizenship in contemporary brazil: the effectiveness of democratic institutions
}

\begin{abstract}
In this paper, I present an overview of the formation of two models of participatory political institutions that are linked to the Brazilian redemocratization process and were conceived in order to stimulate citizen participation. I build on the theme of democratic effectiveness in Brazil to analyze the public policy management councils and the ouvidorias (ombuds offices). I evaluate whether they achieve or not the democratic potentials that they were invested with at the time of Brazilian redemocratization, more than twenty years ago. If, on the one hand, the public policy management councils have been increasingly studied by Brazilian social scientists in recent years, on the other hand, the ouvidorias are much less studied and were almost forgotten by sociologists and political scientists. The main objective of this paper is to investigate the potentials and limits of these two participatory institutions in a comparative perspective. After a few words about the redemocratization context, I present several research remarks about these institutions to evaluate how far they achieve their participatory roles. Comparing my own research on federal ouvidorias with the work of other researchers on councils, I conclude that the low level of institutional autonomy undermines the effectiveness of the democratic potential that is inherent to their idealistic conceptions.
\end{abstract}

Volume I Issue I - 2017

\author{
Fernando Lima Neto \\ Professor of Political Science, Pontifical Catholic University of \\ Rio de Janeiro, Brazil
}

\begin{abstract}
Correspondence: Fernando Lima Neto, Deparment of Political Science, Pontifical Catholic University of Rio de Janeiro, Brazil, Email fercaline@gmail.com
\end{abstract}

Received: April 27, 2017| Published: June 09, 2017

\section{Introduction: the brazilian redemocratization}

The 1980's are an important turning point in the history of Brazilian democracy, when the relations between state and society began to take unprecedented directions. Through many centuries, and under various institutional forms, such as Colonial State, Imperial State and the different facets of Republican States, the Brazilian State kept a constant authoritarian bias in its relationship with society. Since the early colonial era, with rare periods of exception, an authoritarian conception of State has inhibited the autonomous development of society. The concept of patrimonialism, broadly defined as a traditional form of authority in which the private and public spheres overlap, was one of the conceptual ways that social scientists found in order to summarize all the obstacles that undermined the progress toward democracy. In this regard, participatory institutions, as councils, ouvidorias, public audiences, participatory budgets and others were conceived as counter power mechanisms whose main purpose was to consolidate public spaces and political arenas that could help to finally further citizenship. The Brazilian Federal Constitution of 1988 reflected this challenge as it set up participation as an important guideline to politics in Brazil. ${ }^{1,2}$ More than twenty years after the highly enthusiastic expectations raised by these institutions, contemporary sociologists and political scientists are more concerned with the assessment of their democratic effectiveness. I propose here to briefly consider the progress, limits and potentials of councils and ouvidorias.

\section{Councils}

Most of the analyses on the Brazilian public policies management councils present them as the greatest and most innovative institutional change after the redemocratization. Nevertheless, they often highlight the precarious level of effectiveness of these institutions..$^{3-5}$ The highly praised institutional format and democratic functions of these councils are far from being fully developed. Despite the lack of a general institutional form encompassing the plurality of councils, there are several features that are useful in defining a council. These institutions are political arenas created by the State in order to encourage social control at the federal, the state and the municipal levels. A council is generally formed by representatives of the State, of civil society and sometimes of market actors that have regular meetings to engage in discussion and decision-making about public policies. Nowadays, more the 40.000 councils are present in Brazil, ${ }^{6}$ most of them at the municipal level. Often, they are a requisite for the transfer of public resources from national government to municipalities, covering a diversity of thematic areas, such as health, social care, education, security, childhood, employment, environment, minorities, etc. The main results of past and ongoing researches on Brazilian councils tend to stress a wide range of limitations which may be systematized in several topics. First, the persistence of a traditional political culture related to patrimonialism, clientelism and atuhoritarism is often presented as an important obstruction to achieve social control. One can mention the work of Duran ${ }^{7}$ who did a case study about the health council of Rio de Janeiro and showed that the administrative and procedural rules of this council inhibit social control. The representatives of civil society and those of health professionals have diminished opportunities of political autonomy in a deliberative political arena controlled by the representatives of the State. Their role is restricted to carrying out the administrative tasks necessary to release public funding for the health system. The event of the National Health Conference, the major event that gathers thousands of health councils every four years to discuss and deliberate on health public policies, is taken as an example of the diminished weight of society actors insofar as it prohibits the entry of non-representative actors who may be interested in attending the Conference. Another constraint that undermines the democratic potentials of these institutions is bureaucratization. This problem is analyzed by ${ }^{5}$ in his work on rural development councils. Abramovay shows that the quantitative criteria used to choose the poorest and smallest municipalities in government programs turns into a political tool that ensures access to public funding by local elites. The author shows the necessity of 
incorporating qualitative criteria that could support the consistence of the projects, its innovations and the social capital present in the locality. The lack of popular participation, as mentioned by Duran and others authors, is also an important limitation to the effectiveness of this institution. Although non-representatives can attend the meetings of rural development councils, this almost never happens.

The researches on social care councils highlight another obstacle to the effectiveness of this model of participatory institution, which is the fact that they are often a mere legal condition to obtain public funding. The work of $\mathrm{Cruz}^{8}$ reveals that only $2 \%$ of social care councils were created before the formulation of the federal law (LOAS) that regulate public funding on social care in municipalities. This problem is also noted by researchers of health, education, rural development and other themes concerning public policy councils. Another obstacle presented by social care councils studies is the absence of the target public that receives social care (poor, sick and underprivileged people), as analyzed in the work of Degenszajn. ${ }^{9}$

\section{Ouvidorias}

The historical roots of the ouvidorias in Brazil go back to the eighteenth century, in the Imperial time. However, it was only in the last quarter of the twentieth century, during the re-democratization process, that this institution was named ouvidoria and began to have a more marked presence within Brazilian governmental organizations as one of the participatory institutions. ${ }^{10}$ The main purpose of an ouvidoria is to incorporate citizens' contributions to the daily activities of governmental organizations. They are supposed to create a political arena where citizens can express their discontents, ask for information and make any kind of suggestion to governmental organizations. All governmental organizations have or should have their respective ouvidoria. If a governmental organization fails to respond to citizens demands, they can appeal to its ouvidoria in order to have more satisfactory treatment from it.

Currently, the ouvidoriasare fully institutionalized. There are over 1.000 ouvidorias at the federal, state and municipal levels. Most of them are established in municipalities, as in the councils' case, which reflects the decentralization process that followed the Brazilian redemocratization. Although they are institutionally consolidated, little is known about these institutions. Whether in the academic field or in State statistics, there are few studies and information on this wide universe. In the research that I conducted in the Institute for Applied Economic Research (IPEA), we took into account the regulations of 93 ouvidorias at the federal level in order to analyze the conditions of political autonomy that they are granted. The research results reveal precarious conditions for the achievement of their democratic potentials. The main problem concerns the mechanisms of choice of the highest authority of an ouvidoria. Often the person who fills this position is chosen by the highest authority of the organization that should be socially controlled. Thus, for example, the chief of the ouvidoria of the Ministry of Sports is chosen by the Minister himself. This clearly imposes serious limits to ouvidoria's political autonomy, a basic condition for the accomplishment of their democratic roles. The absence of practices of accountability is another limitation that undermines the democratic potentials of the ouvidorias. Often, their legislation provides practices of accountability for the individual claimant but there are no returns to society beyond the individual himself. Only a few legislations have practices of accountability aimed at the broader society, generally through activity reports published on their websites. Another commonly found problem in the ouvidorias' regulations is their little ability to influence the administration of the governmental organizations they are attached to. Indeed, most part of the regulations reduce the role of the ouvidorias to a mere repository for criticism and suggestions without any influence over the decisionmaking process of governmental organizations. The lack of time delimitation for the term of the ouvidorias' highest authority is also an obstacle to their effectiveness. In several cases, some chiefs occupy their position for more than 10 years. In general, all these problems reduce significantly the possibility of turning ouvidorias into an effective participatory institution. The current way that the chiefs of ouvidoriasare nominated, the lack of time delimitation for the duration of their terms, the reduced influence on the decision-making process of governmental organizations and the absence of accountability practices aimed at the broader society are the main obstacles that threaten social control and participation within these institutions, as well as reinforce the patrimonialist features they were supposed to counter. The absence of a common design of these legislations results in too heterogeneous institutional universe, making it difficult to consider them as a whole. In some cases, indeed, the research team wasn't able to identify the specific legislation that rules the ouvidoria, despite the efforts of the researches that repeatedly contacted them without any return.

\section{Closing remarks: councils and ouvidorias in a comparative perspective}

The Brazilian Federal Constitution of 1988, the so-called "citizen Constitution", spread and reinforced several experiences of participation that formerly had a disjointed existence. Councils and ouvidorias were then empowered as important participatory institutions that were supposed to reinforce democratic governance. At that time, the focus on participation as an input for developing democratic political representation created highly enthusiastic expectations concerning the future of democracy in Brazil. However, current studies on participatory institutions in general and on councils and ouvidorias in particular show a wide distance between the formal purpose of these institutions and their actual conditions to improve democracy. Councils and ouvidorias face common challenges that should be overcome in favor of the effectiveness of their potential contributions to democratic governance in Brazil. The main challenge is to confer them enough political autonomy to promote social control. Concerning councils, this means that the representatives of civil society must take part in the discussions and decision-making processes that are held in these arenas. Recent studies have revealed that in the last years the number of representatives of civil society has been increasing, while that of State representatives begins to decrease in health councils. ${ }^{4}$ Besides the expansion of the representatives of civil society, it is important to guarantee the appropriate conditions to make them full protagonists of public policies and also incorporate sectors of society that may not necessarily have formal representatives. Concerning the ouvidorias, the challenges to accomplish political autonomy are even greater. The first step should be to provide legal frameworks that enable effective social control and defines more clearly the democratic functions that they should develop. Nowadays, Brazilian public ouvidorias are generally perceived as their counterpart in market, where they provide a representation of the company in front of the consumer. In governmental organizations, rather than representing the State in front of the citizens, they should represent society within governmental organizations. The challenges 
that both councils and ouvidorias must face are also linked to a broader reformulation of political culture in Brazil, usually associated to authoritarism, clientelism and patrimonialism. The capillary structure of both councils and ouvidoriasis a powerful tool to achieve this objective inasmuch as they permit to bridge the gap between citizens and the State. The recent protests that have spread throughout Brazil are a convincing sign that the political culture is undergoing important changes. Participatory institutions have a major role in this process. Instead of re-translating traditional political grammars, participatory institutions should introduce the influence of society within the State.

Table I Effectiveness (formal purpose and current situation) and challenges of councils and ouvidorias.

\begin{tabular}{llll}
\hline & Formal Purpose & Current Situation & Main Challenges \\
Councils & $\begin{array}{l}\text { Promote social control through } \\
\text { direct participation in deliberative } \\
\text { forums on public health policy. }\end{array}$ & $\begin{array}{l}\text { Councils are merely formal requirements for the } \\
\text { transfer of municipal public funds. The presence of } \\
\text { the representatives of the society does not assure } \\
\text { their effective participation. }\end{array}$ & $\begin{array}{l}\text { Rebalance relations between } \\
\text { representatives of the State and } \\
\text { representatives of society. Qualify and } \\
\text { reinforce the representatives of society. }\end{array}$ \\
\hline Ouvidorias & $\begin{array}{l}\text { Promote social control by } \\
\text { incorporating citizen participation } \\
\text { as a way to improve the } \\
\text { functioning of state institutions. }\end{array}$ & $\begin{array}{l}\text { Lack of specific legislation implies the absence } \\
\text { of accountability practices and reduced political } \\
\text { autonomy. }\end{array}$ & $\begin{array}{l}\text { Consolidate a specific legislation } \\
\text { to strengthen the contribution of } \\
\text { ouvidorias to democracy. }\end{array}$
\end{tabular}

\section{Acknowledgements}

None.

\section{Conflict of interest}

The author declares no conflict of interest.

\section{References}

1. Luis Felipe M. Democracia e representação. São Paulo: UNESP; 2014. $331 \mathrm{p}$.

2. Leonardo A. Sociedade civil, instituicoes participativas e representacao: da autorizacao a legitimidade da açao. Dados. 2007;50(03):443-464.

3. Vera Schattan Coelho P. Brazil's health councils: the challenge of building participatory political institutions. IDS Bulletin. 2014;35(2):33-39.

4. Soraya. Conselhos e conferências de saúde: papel institucional e mudança nas relações entre Estado e sociedade. Fleury, Sonia; Lobato, Lenara, editors. Participação, democracia e saúde. Rio de Janeiro: CEBES; 2009.
5. Ricardo Abramovay. Conselhos alem dos limites. Estudos Avançados. 2001;15(43):121-140.

6. IBGE. Perfil dos municípios brasileiros. Pesquisa de informações básicas municipais. Rio de Janeiro, Departamento de População e Indicadores Sociais. 2012.

7. Paulo D. Dilemas do controle social na construção do Sistema Único de Saúde (SUS) no âmbito do estado do Rio de Janeiro: um estudo sobre o Conselho Estadual de Saúde (CES/RJ). PhD Thesis. Fundação Oswaldo Cruz. Rio de Janeiro. 2013.

8. Maria C. Desafios para o funcionamento eficaz dos Conselhos. In: Carvalho, Cortês Maria, Teixeira, Ana, editors. São Paulo: Conselhos Gestores de Políticas Públicas; 2000.

9. Degenszajn, Raquel. Esfera pública e conselhos de assistência social: caminhos da construção democrática. São Paulo: Cortez; 2005. p. 1-20.

10. Rubens L. Autônomas x obedientes: a ouvidoria pública em debate. Paraíba: UFPB; 2004. 